\title{
The Influence of Student Involvement, Religiosity, and Peer Influence on Lifelong Learning Skills as Mediated by Teacher Support
}

\author{
Jolly S. Balila ${ }^{1}$ Pamela H. Heng ${ }^{2 *}$ Sri Tiatri ${ }^{2}$ Edwin A. Balila ${ }^{1}$ \\ Miriam P. Narbarte ${ }^{1}$ Raja O. Tumanggor ${ }^{2}$ \\ ${ }^{1}$ Research Office, Adventist University of the Philippines \\ ${ }^{1}$ College of Science and Technolgy, Adventist University of the Philippines \\ ${ }^{1}$ College of Business, Adventist University of the Philippines \\ ${ }^{2}$ Faculty of Psychology, Universitas Tarumanagara \\ Corresponding author: pamelah@fpsi.untar.ac.id
}

\begin{abstract}
This study explored how students' involvement, religiosity, and peer influence affect the lifelong learning skill of college students as mediated by teacher support using structural equation modeling. A cross-sectional design was applied using survey questionnaires utilizing 593 randomly selected college students enrolled in a faithbased university. All statistical outputs were generated using SPSS version 23 and SMART PLS. Results revealed that more college students were involved in small groups, professional organizations, and campus sports programs for more than three semesters compared to other extracurricular activities. College students have friends who influence them and in their intellectual growth, attitude, values, and other aspects of influence and teachers show supported them academically, emotionally, and spiritually. They were also involved in different religious practices and perceived that their lifelong learning skills were developed during their stay in the university. This study concludes that teacher support fully mediates the influence of student involvement in extracurricular activities and the percieved lifelong learning skills but partially mediates with peer influence on lifelong learning skills. However, religiosity directly influences the perceived lifelong learning skills of the college students. Recommendations are discussed on how to enhance involvement, peer influence, religiosity, and the role of teachers to develop the lifelong learning skills of college students.
\end{abstract}

Keywords: Mediation analysis, students’ involvement, religiosity, peer influence, social support

\section{INTRODUCTION}

Many universities are ignoring the examination of the lifelong learning skills during their stay in the university. Numerous studies revealed that students' college experiences can contribute to such development [1][2]. These can be their experiences with their professors, interaction with other students, and by being involved in activities inside and outside the classroom.

Involvement in extra-curricular activities is one of the memorable experiences of college students. The experience gained from their involvement is lifelong learning [3] where various skills can be developed. Extracurricular activities (ECAs), when appropriately done and balanced with academic learning, may help students develop their cognitive, affective, and psychomotor skills. However, some students allot more of their time in engaging in so many ECAs sacrificing their academic performance. Study shows that participation in activities was correlated to social and academic success [4].
Peer influence is another factor that can affect the development of a lifelong learning skills of individuals particularly adolescents. The effect can be positive or negative. The choice of friends while in college plays a significant role especially that the neurodevelopmental vulnerability underlying adolescence is susceptibility to peer influence [5]. College students can also be vulnerable to the influence of their peers.

Research on the relationship of religiosity on the development of lifelong learning skills are limited [6]. Assessing religious variables across studies is not explored very well. In a meta-analysis study, it was observed among 63 studies that 10 showed a positive relationship between religiosity and intelligence wherein two were statistically significant. Moreover, 35 of the studies showed a statistically significant negative correlation between religiosity and intelligence. This means that there were correlation results between religiosity and intelligence are conflicting [7]. 
Teachers have a great contribution to students' academic and life-long success [8]. The support of the teacher both in the academic and non-academic activities of the students is associated with their learning outcomes [9]. Studies confirmed that teachers have significant and substantive impacts on their students' academic and life-long success [9][10]. In the aforementioned studies, student involvement in extracurricular activities, peer influence, and religiosity was associated with cognitive - related variables. However, there is a dearth of studies that determined the mediating role of teacher support to these related variables specifically on students lifelong learning skills.

\subsection{Related Work}

\subsubsection{Student involvement in extracurricular activities}

Student involvement is the amount of physical and psychological energy devoted by students in their university [11]. The academic experience can pertain to the college students' involvement in ECAs. ECAs can be defined as academic or nonacademic activities that are conducted under the auspices of the school but occur outside of normal classroom time and are not part of the curriculum [12]. Involvement in these activities is optional among students and does involve a grade or academic credit. They interact frequently with other students and teachers on the campus. Involvement in extracurricular activities is associated with a range of positive outcomes [13], however, these results may not apply to all ECAs. Studies revealed that participation in ECAs is correlated with higher scores and better psychological, behavioral outcomes [14][15]. Moreover, ECAs are associated with the balanced and holistic development of students. Values are formed aside from the cognitive aspects as students interact with peers and their teachers. When skills are developed, these students can become a holistic human capital [17]. On the other hand, ECAs can negatively impact student performance [18]. These contradicting issues on the effect of student involvement in ECAs need to be studied more due to these conflicting results.

\subsubsection{Peer influence}

Peer influence is something people do because they want to be accepted and valued by friends. Most often a person behaves to feel they belong to a group of friends or peers. Peer influence can be positive or negative. Peer influence has a great role in shaping the success of students. Students become more motivated to maximize their learning and exceed their capability if supported by a peer group [19]. Collaborative learning promotes a positive learning atmosphere that it supports learning autonomy. Students feel free to discuss, interact, encourage, and learn from one another [20].

\subsubsection{Religiosity}

In general, religion is a vital part of human lives. It is considered the driving force in people's daily lives. "Religiosity is defined as the adherence to beliefs, doctrines, ethics, rituals, texts, and practices associated with a higher power either alone or among organized groups”. It was found that there is a positive relationship between intelligence and religiosity. The values learned from being religious can be associated to their development of various skills [21][22].

\subsubsection{Teacher support}

The existence of an academic institution is vital among students. Academic institutions should stimulate students' integral development within three domains of knowledge: affective, cognitive, and psychomotor. The teachers are the initiators of this development among students. They play a decisive part in the success of the students. Once students leave the portals of their university, they carry the gains based on their college experiences. Previous studies explain the influence of the teacher on the success of the learners. Teachers influence inside and outside the classroom is affecting the students' learning process [24][25] The teachers' role is important "because they are ultimately responsible for translating policy into action and principles based on practice during interaction with students" [26, p.28].

\subsubsection{Lifelong learning skills}

College and career readiness depends on students acquiring a complex set of skills from formal or non-formal education [27]. Lifelong learning is a form of initiated education for the purpose of personal development. The skills developed may not be a product of formal schooling. The lifelong learning skills or competencies are often referred to as "21st century skills". Career readiness is being link to this 21st century skills. The 21st century skills include critical thinking skills, creativity, collaboration, and communication [28].

This study uses the Input-Environment-Output (IEO) model developed by Alexander Astin in 1993 [28]. This theory implies that deciding to change something for the better would imply that a new element or environment will result in a much better outcome. Astin stressed that the greater the student's involvement in different activities in college, the greater will be their learning and personal development. This explains the views that involvement in different collegiate activities affect the students' development and transformation as desirable outcomes of higher education institutions. This theory has three core concepts: (a) inputs, (b) environment, and (c) outcomes. Inputs pertain to their demographics, background, and any previous experiences. Environment comprises all the experiences of the students throughout their college years. Outcomes involve their characteristics, knowledge, attitudes, beliefs, and values after graduating from college [29]. The Social Cognitive 
Theory (SCT)- also supports this study where it describes the influence of individual experiences, the actions of others, and environmental factors on individual behaviors. SCT provides opportunities for social support through instilling expectations and other reinforcements to achieve behavior change.

\subsection{Our Contribution}

The research gaps were addressed in this study by examining the predictors of the perceived lifelong learning skills among college students in a faith-based university as mediated by teacher support. The following objectives were addressed:

1. Determine the college students tinvolvement in extracurricular activities, peer influence, religiosity, teacher support, and student's skills.

2. Determine the degree of relationships among variables and significant predictors of lifelong learning skills, and

3. Examine the influence of student involvement, peer influence, and religiosity on students' lifelong learning skills as mediated by teacher support.

\subsection{Paper Structure}

The succeeding part of this study discussed section 2 which described the background of this study. Section 3 presents the methods used to address the objectives of the study. Section 4 presents the findings and discussion of the present study. Implications were discussed and served as a basis for policy making for a better service for students.

\section{BACKGROUND}

The study was conducted in a faith-based university and was approved as the basis for student-related policies and further improved the services of the university.

\section{METHODS}

Study Design. Cross-sectional design was applied to collect the data necessary to answer the objectives of this study. The study was conducted among college students in a faithbased university in Silang, Cavite, Philippines

Population and Sampling Technique. A total of 593 randomly selected undergraduate students enrolled in a faith-based university were included in the study. In this study, the proportion of male (46.7\%) and female (53.3\%) respondents were represented. The respondents were Freshmen (21.1\%), Sophomore (28.7\%), Junior (28.2\%), Senior (22.1\%) college students. The mean age was 22.32 $(S D=3.05)$ years old and the mean number of semesters they stayed in the University was approximately 6 years $(5.76, S D=3.43)$.

Instrumentation. A questionnaire was developed to assess the students' involvement in extra-curricular activities, religiosity, peer influence, teacher support, and lifelong learning skills. It also included the profile in terms of sex, year level, age, and the number of semesters attended the university. The questionnaire underwent content validation and a pilot study to test the internal consistency of the items. Cronbach's alpha reliability was computed for religiosity (.925), student involvement (.855), teacher support (.951), peer influence (.924), and lifelong learning skills (.926).

Procedure. The approval of the Ethics Review Board was secured before the final data gathering. The researcher distributed the questionnaires to the students in their respective dormitories inside the university after securing approval from the dormitory deans who stands as their guardian. Anonymity and confidentiality were assured for the respondents.

Data Analysis. The data analysis was performed using Statistical Package for the Social Sciences (SPSS) and SMART PLS. Specifically, the following statistical tools were used: frequency count, mean, Pearson productmoment correlation, and multiple regression. To determine the mediation effect, SMART PLS was used.

\section{FINDINGS AND DISCUSSION}

\section{Student Involvement in Extra-Curricular Activities}

The results showed that students were involved more in small groups for more than three semesters. Moreover, more students (52.45\%) were involved in the campus sports programs, professional club organizations (50.59\%), and choir (42.33\%). Furthermore, students were also involve in campus student organization, on campus work-drive (32.04\%), campus publications (28.16\%), and small groups (18.04\%).

\section{Peer Influence}

The 5-point Likert scale response (Strongly disagree, Disagree, Uncertain, Agree, Strongly Agree) revealed that the mean values fall on the scaled response "Agree" on all the nine items of peer influence. The results imply that students have friends who influenced them in their intellectual growth, attitude, values, and by enriching their classroom experiences. Since they were enrolled in a faithbased university, it is manifested that their peer positively influenced their walk with their God by attending worship services, by praying, and study the Bible together. The overall mean of $3.92(\mathrm{SD}=.66)$ implies that peers positively influence the college students in the university.

\section{Religiosity}

Religiosity was measured in terms of the 14 items. The result revealed that students often attend church and /or campus worship services and have personal prayer and meditation. The other items of religiosity were sometimes practiced by the college students like participating in a prayer group, mentoring someone, and participating in the outreach programs. The overall mean of $3.13(S D=.826)$ revealed that college students were moderately involved in religious activities on the university campus. 


\section{Teacher Support}

The respondents of the study were asked to "think of their professors they were acquainted within the university and how often do they give their support. The college students perceived that their professors often supported them academically, intellectually, emotionally, and spiritually. Some of the support provided by their teachers are: "really challenge me academically (3.95)," "help me meet my academic challenges (3.85)", "integrate values and ethics in the classroom (3.89)", and "positively influence my intellectual growth (3.89)". In addition, three items "study the Bible with me", "increase my faith in the Bible", and "provide a meaningful classroom experiences" were perceived to be sometimes practiced by their professors. This may be true since not all professors are teaching Bible courses. When students feel that their teacher cares and sincerely expects them to learn, they will be happy and have fun in learning as well as other learning activities without pressure [31][32].

\section{Lifelong Learning Skills}

It is the goal of the any university that students developed the lifelong learning skills as their expected gains from their experiences in the university. In this study, students perceived that they developed various lifelong learning skills from the university, particularly decision-making skills $(4.0, \mathrm{SD}=.80)$, writing skills $(3.68, \mathrm{SD}=.97)$, public speaking skills (3.96, $\mathrm{SD}=.87$ ), research skills (3.96, $\mathrm{SD}=.81)$, problem-solving skills $(3.92, \mathrm{SD}=.81)$, critical and analytical thinking skills (3.96, $\mathrm{SD}=.85$ ), creative thinking skills (3.98, $\mathrm{SD}=.88$ ), and professional networking skills $(3,53, \mathrm{SD}=1.03)$. The skills they developed were related to their career path and future job.

\section{Correlation Among Variables in the Study}

The result of this study revealed a significant relationship between extra-curricular activities involvement and lifelong learning skills. The degree of relationship is low $(r=.095$, $p=.021)$. Further results revealed that among the variables that were analyzed from the relationships with lifelong learning skills of college students, teachers support had the highest degree of relationship ( $r=.505, p<.001$ ), followed by peer support $(r=.379, p<.001)$, and religiosity $(r=.294$. $p, .001)$. Student involvement had the lowest degree of relationship. Active student participation in ECAs outside the classroom environment allows the students to interact with teachers and friends. Further, athletics participation was positively correlated with student outcomes. The influences from the peer were significantly correlated to the perceived lifelong learning skills development of college students with a moderate degree of relationship $(r=.379, p$ $<.001)$.

\section{Significant Predictors of Lifelong Learning Skills}

The results of regression analysis revealed that peer influence and religiosity were significant predictors. The regression model $\{\mathrm{Y}=2.43+0.32$ (peer influence) +0.14 (religiosity) $+\mathrm{e}$ \} explained a total of $17 \%$ of the variation in lifelong learning skills $(F(2,580)=59.56, p<.001)$, $14.3 \%$ of the variation in lifelong learning skills is explained by peer influence and $2.7 \%$ can be explained by religiosity. Further results revealed that teacher support significantly predicts the lifelong learning skills of the college students, having $25.5 \%$ of the variation in lifelong learning skills is explained by teacher support $(F(1,584)=$ 200.3), $p<.001)$. The regression model generated from this analysis is $\mathrm{Y}=2.41+.42$ (teacher support) $+\mathrm{e}$.

\section{Mediation Analysis}

The result of the mediation analysis in Figure 1 revealed that teacher support fully mediates the influence of student involvement (campus activities) on lifelong learning skills of the students This means that student involvement in school activities outside their classroom can develop the lifelong learning skill of college students. However, this is not possible if there is no support from the teachers. Learning and personal development during college years inside and outside the classroom can be achieved by engaging in academic and non-academic activities. Researchers who study the impact of college life on students agree that what happens outside the classroom can contribute to the valuable outcomes of college [33]. 


\section{Structural Equation Model}

Figure 1 Structural equation model on lifelong learning skills

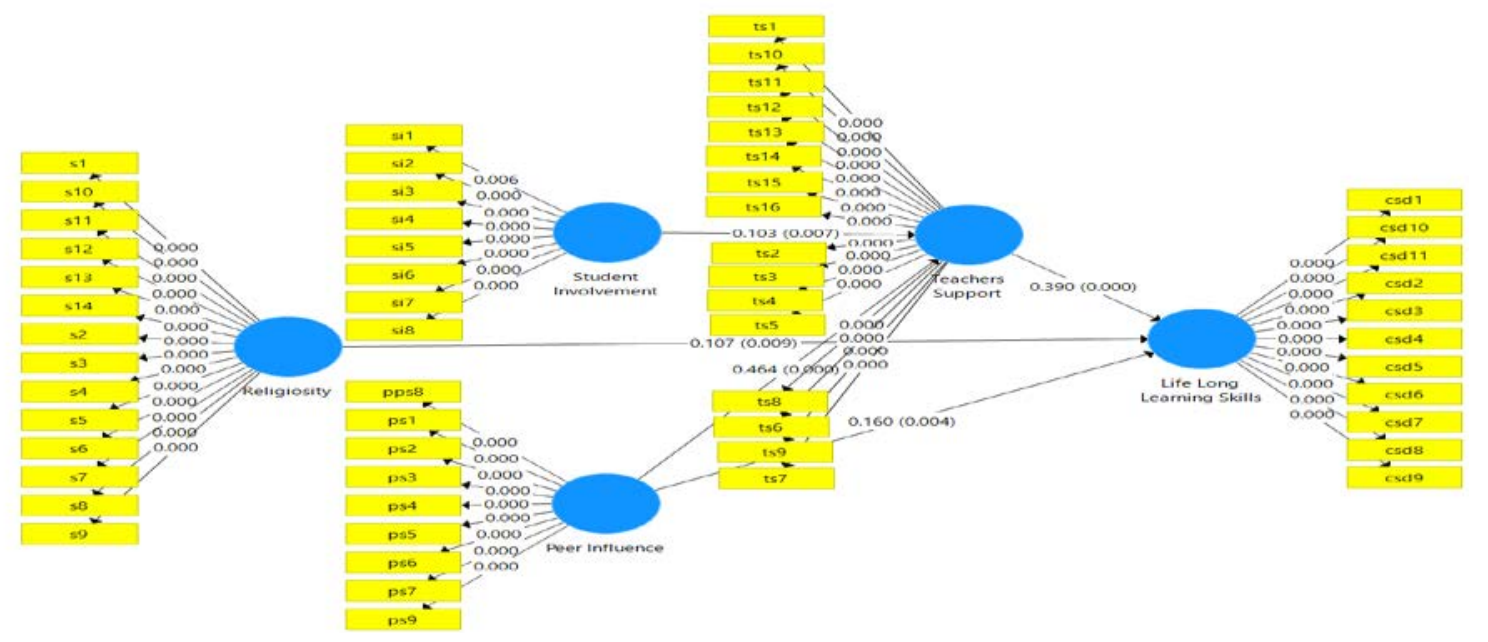

The findings of this study showed that teachers play a significant role in the lifelong learning skills development of college students. The findings suggest that faculty members provide their utmost support psychologically and academically with the students. Teacher support partially mediates the influence of peer influence on lifelong learning skills. This result means that peer influence can improve the lifelong learning skills of the college students. Along with the peer influence is teacher support; both complement students' lifelong learning skill in general. Moreover, religiosity has a direct influence on the student's lifelong learning skills. Further, the latent construct student involvement in extracurricular affected lifelong learning skills. This finding supported previous studies who have found extracurricular engagement to positively affect lifelong learning skills [34].

Table 1 Mediation analysis in PLS-SEM

\begin{tabular}{|c|c|c|c|c|c|c|c|c|}
\hline Effects & Path & $\begin{array}{l}\text { Path } \\
\text { Coefficient }\end{array}$ & $\begin{array}{l}\text { Indirect } \\
\text { Effect }\end{array}$ & $\begin{array}{l}\text { Total } \\
\text { Effect }\end{array}$ & t-value & $\begin{array}{l}\mathrm{p}- \\
\text { value }\end{array}$ & Decision & $\begin{array}{l}\text { Type of } \\
\text { Mediation }\end{array}$ \\
\hline Direct without Mediator & $\begin{array}{l}\text { PI -> LLS } \\
\text { PI }->\text { TS }\end{array}$ & $\begin{array}{l}0.16 \\
0.464\end{array}$ & NA & $\begin{array}{l}\text { NA } \\
\text { NA }\end{array}$ & $\begin{array}{l}2.932 \\
12.24\end{array}$ & $\begin{array}{l}0.003 \\
0\end{array}$ & Accepted & NA \\
\hline Indirect with Mediator & $\begin{array}{l}\text { TS -> LLS } \\
\text { PI -> LLS }\end{array}$ & 0.39 & 0.181 & 341 & $\begin{array}{l}8.928 \\
6.177\end{array}$ & $\begin{array}{l}0 \\
0\end{array}$ & $\begin{array}{l}\text { Accepted } \\
\text { Accepted }\end{array}$ & $\begin{array}{l}\text { Partial } \\
\text { Mediation }\end{array}$ \\
\hline Direct without Mediator & $\begin{array}{l}\text { SI }->\text { LLS } \\
\text { SI }->\text { TS }\end{array}$ & $\begin{array}{l}\text { NA } \\
0.103\end{array}$ & NA & $\begin{array}{l}\text { NA } \\
\text { NA }\end{array}$ & 2.659 & 0.008 & & NA \\
\hline Indirect with Mediator & $\begin{array}{l}\text { TS -> LLS } \\
\text { SI -> LLS }\end{array}$ & 0.39 & .04017 & .0402 & $\begin{array}{l}8.928 \\
2.567\end{array}$ & $\begin{array}{l}0 \\
0.01\end{array}$ & Accepted & Full \\
\hline
\end{tabular}

Legend: $\quad P I=$ Peer Influence $\quad$ LLS = Lifelong Learning Skills $\quad T S=$ Teachers Support SI = Students Involvement Rel $=$ Religiosity

In Table 1, peer influence has a positive effect on the lifelong learning skills with a path coefficient of 0.16 ( $t=$ 2.932, $p=0.003)$. This means the stronger the peer influences the more the lifelong learning skills are developed among college students. Peer indeed influences teacher support with a path coefficient of 0.464 which implies that when peer influence goes up by one standard deviation, the lifelong learning skills goes up by 0.464 standard deviation. Hence as peer influence increases, there is the likelihood that teacher support also increases.

In the same vein, as teacher support increases by one standard deviation, lifelong learning skills increases by 0.39 standard deviation. Thus, teacher support influences the lifelong learning skills. From the given argument, teacher support turned out to be the mediator of peer influence on lifelong learning skills. Since the direct effects of peer influence on lifelong learning skills is significant, it implies that teacher support is partially mediating the effects of peer influence on lifelong learning skills development, and its total effect is $0.16+0.181=.341$. Therefore, with the presence of teachers' support, peer influence on lifelong learning skills increases from 0.16 to 0.34 . From the model, student involvement is not directly related to the developed lifelong learning skills but positively related to teacher support with the path coefficient of $0.103(t=2.66, \mathrm{p}=.01)$. This indicates that teacher support increases by 0.103 standard deviation for every standard deviation unit of student involvement. Also, teacher support is positively influencing lifelong learning skills. Hence, teacher support is a mediator of student involvement in lifelong learning 
skills and the type of mediation is "full". Lastly, the table indicates that religiosity has an influence on the lifelong learning skills with a path coefficient of 0.107 which simply means that for a unit standard deviation of religiosity there corresponds a 0.107 standard deviation of the lifelong learning skills.

Table $2 \mathrm{R}^{2}$ and $\mathrm{Q}^{2}$ values

\begin{tabular}{lrr}
\hline Endogenous LVs & $R^{2}$ Value & $\begin{array}{l}\text { Stone- } \\
\text { Geisser's } \\
Q^{2} \text { Value }\end{array}$ \\
\hline Teachers Support & 0.235 & 0.134 \\
Lifelong Learning Skills & 0.290 & 0.164 \\
\hline
\end{tabular}

The $\mathrm{R}^{2}$ value indicated the proportion of variance of the dependent variable explained by the independent variable Likewise, the value represents a measure of how well the path model can predict the originally observed values (Hair et al., 2017). Table 2 shows that peer influence and student involvement contribute $23.5 \%$ of the variance of teachers and maintain a predictive Stone-Geisser's value of 0.134 . Similarly, teachers' support, peer influence, and religiosity associated $29 \%$ in the variance of lifelong learning skills and maintain a predictive Stone-Geisser's value of 0.164. Similarly, religiosity, peer influence, and teachers support contribute $29 \%$ of the variance proportion of lifelong learning skills with a predictive value of 0.164 .

The teacher support has an acceptable effect size $f^{2}$ of 0.159 on lifelong learning skills. While peer influence and religiosity have respectively effect sizes $f^{2}$ of 0.026 and 0.013 . Such results are considered very low. Likewise, peer influence has an acceptable effect size $f^{2}$ of 0.278 on teacher support while student involvement has an effect size of 0.014 on teachers' support which is considered low. The interpretation was based on the ranged of 0-.02 (No effect), 0.02-0.14 (Small effect), .15-.34 (Medium effect), and .351 .0 (Large effect).

\section{CONCLUSIONS}

This study concludes that teacher support fully mediates the influence of student involvement in on-campus extracurricular activities and lifelong learning skills. Student involvement in school activities outside their classroom can improve the lifelong learning skills of college students. Without teacher support, the students' involvement in ECAs cannot directly influence lifelong learning skills. However, this is not possible if there is no support from the teachers. The development lifelong learning skills during college years is facilitated by teachers who served as guardians and mentors at the same time since these college students were away from their parents. Added to the aforementioned conclusion is that peer influence and teacher support; both complement to enhance students' lifelong learning skills. As the results of the mediation study showed that teacher support partially mediates the influence of peer on lifelong learning skills. Religiosity has a direct effect on the perceived lifelong learning skills of college students. Being religious can improve students' lifelong learning skills. Students who pray and have personal devotion with God, study the Bible, fellowship with co-believers, and do witnessing are more likely to develop lifelong learning skills during their college days. Hence, providing a good environment for the students will enhance the effects of student involvement, peer influence, and religiosity on the lifelong learning skills of the students. More so, the study confirms Astin's theory on input-environment-output and the socio-cognitive theory. The results of these mediation study were used as basis for drafting student policy on programs in the university related to student in-campus and off campus activities, religious, and teacher mentoring program.

\section{ACKNOWLEDGMENT}

This work was funded by Research \& Community Service of Universitas Tarumanagara, led by Ir. Jap Tji Beng, Ph.D. The researchers are grateful to the Faculty of Psychology, Universitas Tarumanagara especially to the Dean of Psychology who has given the unceasing support for this International Collaboration research.

\section{REFERENCES}

[1] K. Bista, \& C. Foster. Issues of international student retention in American higher Education. The International Journal of Research and Review, 7(2) (2011) pp. 1-10. https://files.eric.ed.gov/fulltext/ ED525791.pdf

[2] Y. K. Kim, D. Edens, M.F. Iorio, J.C. Curtis, \& E. Romero (2015). Cognitive Skills Development Among International Students at Research Universities in the United States. Journal of International Students, 5(4) (2015) pp. 526-540. Https://www.ojed.org/index.php/ jis/article/view/413

[3] A. Han \& K. Kwon, Students' perception of extra curricular activities: a case study. Journal of Advances in Educational Research, 3(3) (2018) pp.130-141. DOI: 10. 22606/jaer.2018.33002

[4] R. Freeman, The relationship between extracurricular activities and academic achievement. Dissertations. (2017) 245. DOI: https://digitalcommons.nl.edu/diss/ 245

[5] D. Albert, J. Chein, \& L. Steinberg, Peer influences on adolescent decision making. Current Directions In 
Psychological Science, 22(2) (2013) pp.114-120. DOI: https://doi.org/10.1177/0963721412471347

[6] J. Sickles, K. Schrantz, \& C.W. Lack, The Relationship between Intelligence and religiosity: A critical review of the literature. Journal of Scientific Psychology, (2015) pp 1- 10. file://C:/Users/user/ Downloads/TheRelationshipbetweenIntelligenceandRel igiosity-2.pdf

[7] M. Zuckerman, J. Silberman, \& J.A. Hall, The relation between intelligence and religiosity: A metaanalysis and some proposed explanations. Personality and Social Psychology Review, 17(4) (2013) pp. 325354.

[8] D. Blazar, Teacher and Teaching Effects on Students' Academic Performance, Attitudes, and Behaviors. Doctoral dissertation, Harvard Graduate School of Education. (2016) Retrieved from https://dash.harvard. edu/bitstream/handle/1/27112692/BLAZAR-

DISSERTATION-2016.pdf?sequence $=1$ \&isAllowed=y

[9] M. Kang, \& T. Im, Factors of learner-instructor interaction which predict perceived learning outcomes in online learning environment, 29(3) (2013) 292-301. article. http://doi.org/10.1111/jcal.12005

[10] R. Chetty, J. N. Friedman, \& J. E. Rockoff, Measuring the impacts of teachers I: Evaluating Bias in Teacher Value-Added Estimates. American Economic Review, 104(9) (2014) pp. 2593-2632.

[11] K. Farley, M. McKee, M. Brooks, The Effects of Student Involvement on Graduate Student Satisfaction: A Pilot Study. Alabama Counseling Association Journal, 37(1) (2011) pp. 33-38. DOI: https://files.eric. ed.gov/fulltext/EJ954288.pdf

[12] K. R. Bartkus, B. Nemelka, M. Nemelka, \& P. Gardner, Clarifying the meaning of extracurricular activity: A literature review of definitions. American Journal of Business Education, 5(6), (2012) pp. 693-704.

[13] A. F. Farb \& J. L. Matjasko, (2012). Recent advances in research on school-based extracurricular activities and adolescent development. Developmental Review, 32, (2012) 1-48. DOI:10.1016/j.dr.2011.10.001

[14] A. Denault, \& M. Déry, Participation in Organized Activities and Conduct Problems in Elementary School: The Mediating Effect of Social Skills. Journal of Emotional and Behavioral Disorders 23(3) (2015) pp. 167-79.

[15] D. S. Morris, Actively Closing the Gap? Social Class, Organized Activities, and Academic Achievement in High School. Youth \& Society 47(2) (2015) pp. 26790.

[16] R. Freeman, The relationship between extracurricular activities and academic achievement. (2017). Dissertations. 245. https://digitalcommons.nl. edu/diss/245

[17] S. A. Manchaa, \& A. Ahmada, Co-curricular activities and its effect on social skills. International Conference on Education and Regional Development 2016 (ICERD 2016) "Cross-Cultural Education for Sustainable Regional Development” file://C:/Users/ user/Downloads/CO_CURRICULAR_ACTIVITIES_A ND_ITS_EFFECT.pdf

[18] M. Correa, B. K. Dumas, C. Jones, V. Victor Mbarika, \& M. Isaac, I. M. Ong'oa, Extracurricular activities and academic achievement: A literature review. Global Advanced Research Journal of Educational Research and Review, 4(9) (2015, September) pp. 165-169, DOI: http://garj.org/garjerr/ index.htm

[19] A. Olalekan, Influence of peer group relationship on the academic performance of students in secondary school (A case study of selected secondary school in Atiba local government area of oyo state). Global Journal of Human Social Science: Arts \& Humanities Psychology, 16(4) (2016) 35 DOI: https:// socialscienceresearch.org/index.php/GJHSS/article/vie w/1826

[20] J. C. Furrer, E. A. Skinner, \& J. R. Pitzer, The influence of teacher and peer relationships on students' classroom engagement and everyday motivational resilience. National Society for the Study of Education, (2014) 101-123.

[21] R. W. Hood, Ralph \& S. Bernard, The Psychology of Religion: An Empirical Approach, (3rd ed). (2003) New York: Guilford Press.

[22] P. Austin, J. Macdonald, \& R. MacLeod, Measuring Spirituality and Religiosity in Clinical Settings: A Scoping Review of Available Instruments. Religions. 10 (2019) 214; DOI: 10.3390/rel10030214

[23] I. Blažević, Family, Peer and School Influence on Children's Social Development. World Journal of Education, 6(2) (2016) 42-49. https://files.eric.ed.gov/ fulltext/EJ1158301.pdf

[24] G. N. Kimani, A. Kara, \& L. W. Njagi, Teacher Factors Influencing Student's Academic Achievement in Secondary Schools in Nyandarua Country, Kenya. 
International Journal of Education and Research. 1(3) (2013).

[25] A. Kosgei, K. M. Jairo, O. Odera, E. A. Mary, Influence of teacher characteristics on student's academic achievement among secondary schools. Journal of Education and Practice. 4(3) (2013) pp. 7682. DOI: https://eprints.usq.edu.au/23286/1/Kosgei.pdf

[26] S. Amaliyah, K. Anwar, \& F. L. Nuqul, F. L. The Effect of Religious Identity towards Academic Performance: An Experimental Study 6th Annual International Conference on Cognitive and Behavioral Psychology (2017) pp. 2251-1865 DOI: 10.5176/22511865_CBP17.6

[27] M.W. McGarrah. American Institutes for Research (2014). Lifelong learning skills for college and career readiness: An annotated bibliography. American Institutes for Research (2014) https:/www.air.org/ sites/default/files/CCRS\%20LifelongLearning\%20Bibli graphy.pdf

[28] Student developemnt Theory (2007). https:// studentdevelopmenttheory.weebly.com/astin.html

[29] E. Kurniawan, S. Muslim, E. Rahmadyanti, W. Aribowo, N. Kusumawati, E. Ismayati, \& I. Basuki, Vocational student's readiness in the face of the Industrial Revolution 4.0 and the demands of life in the 21st Century Skills. Celebes Education Review, 1(1), (2019) pp. 40-52.

[30] Hanover Research, The impact of arts and athletics participation on student success. (2016) https://www.gssaweb.org/wp-content/uploads/2016/04/ The-Impact-Of-Arts-And-Athletics-Participation-OnStudent-Success.pdf

[31] H. Guvenc, The relationship between teachers' motivational support and engagement versus disaffection. Educational Science: Theory and Practice, 15(3) (2015) pp. 647-657.

[32] S. Sengsouliya, S. Soukhavong, N. Silavong, S. Sengsouliya, \& F. Littlepage, (2020). An investigation on predictors of student academic engagement. European Journal of Education Studies, 0. DOI: http:// dx.doi.org/10.46827/ejes.v0i0.2793,

[33] M. H. Im, N. Jan, Q. C. Hughes, \& K. Oi-man (2016). Effects of Extracurricular Participation during Middle School on Academic Motivation and Achievement at Grade 9. American Educational Research Journal 53(5) (2016) pp. 1343-75.
[34] C.R. Glass, Educational experiences associated with international students' learning, development, and positive perceptions of campus climate. Journal of Studies in International Education, 16 (2012) 228-251. 